\title{
Article \\ Not Only Severe Events: Moderate Dry Periods Impact the Hydraulic Functioning and Survival of Planted Ponderosa Pine Seedlings
}

\author{
Carolyn R. Koehn ${ }^{1}\left(\mathbb{D}\right.$, Matthew D. Petrie ${ }^{1, * \mathbb{C}}$ and Robert M. Hubbard ${ }^{2}$ \\ 1 School of Life Sciences, University of Nevada Las Vegas, Las Vegas, NV 89154, USA; carolyn.koehn@unlv.edu \\ 2 USDA Forest Service, Rocky Mountain Research Station, Fort Collins, CO 80526, USA; \\ robert.hubbard@usda.gov \\ * Correspondence: matthew.petrie@unlv.edu
}

check for updates

Citation: Koehn, C.R.; Petrie, M.D.; Hubbard, R.M. Not Only Severe Events: Moderate Dry Periods Impact the Hydraulic Functioning and Survival of Planted Ponderosa Pine Seedlings. Forests 2022, 13, 370 https://doi.org/10.3390/f13030370

Academic Editor: Marta Pardos

Received: 12 January 2022

Accepted: 18 February 2022

Published: 23 February 2022

Publisher's Note: MDPI stays neutral with regard to jurisdictional claims in published maps and institutional affiliations.

Copyright: (c) 2022 by the authors. Licensee MDPI, Basel, Switzerland. This article is an open access article distributed under the terms and conditions of the Creative Commons Attribution (CC BY) license (https:// creativecommons.org/licenses/by/ $4.0 /)$.

\begin{abstract}
Juvenile tree survival will increasingly shape the persistence of ponderosa pine forests in the western United States. In contrast to severe pulse disturbances that induce widespread adult and juvenile tree mortality, moderate periods of low rainfall and warm temperatures may reduce forest persistence by killing juvenile trees at the seedling stage. Intensification of these periods in a changing climate could therefore increasingly restrict both natural regeneration and artificial regeneration of planted seedlings. We conducted a controlled field experiment at a single site in the Front Range of Colorado, USA, to determine the responses and survival of 3 Colorado subpopulations of $<1$ year old potted ponderosa pines to moderately dry conditions, variation in small rainfall events based on observed patterns, and shaded and unshaded microsite environments. Near surface soil moisture increased slightly following small rainfall events, but declined over the 45-day experimental period. Seedling transpiration and associated canopy cooling declined after $\sim 13$ days, and further declines in transpiration and canopy cooling suggest that the majority of trees in lower rainfall treatments experienced hydraulic dysfunction between days $\sim 20-30$. After 45 days, mortality across all subpopulations and treatments, inferred by relative water loss, exceeded 90-95\%. Despite some uncertainty pertaining to the stress tolerance of nursery grown versus naturally germinated conifers, our results show that planted ponderosa pine seedlings $<1$ year old are unlikely to survive moderate dry periods of $20+$ days relying on small rainfall events. Although microsite conditions and soil moisture availability shaped tree hydraulic functioning early in the experiment (days 1-13), later functioning was shaped predominately by the legacy of rainfall treatments. Our results illustrate the importance of moderate dry events that occur consistently as part of seasonal variation in climate, and show how their intensification may constitute a sustained press that limits opportunities for natural and artificial regeneration.
\end{abstract}

Keywords: conifer; precipitation; climate; press disturbance; regeneration; management

\section{Introduction}

The ability of ponderosa pine forests to regenerate in undisturbed and post-disturbance landscapes will increasingly dictate their persistence in the western United States. Increasing temperatures and water limitation associated with climate change are expected to increase juvenile tree mortality [1,2], and climate change is expected to intensify disturbances including drought and wildfire [3-5]. Regeneration declines have been observed throughout the western US [4,6], and both natural regeneration and human-assisted artificial regeneration are often unsuccessful [5,7]. Severe climate and disturbance events impose environmental conditions that seedlings $(<\sim 0-3 \mathrm{y})$ and juvenile trees are not adapted to survive, and have the potential to restrict the fundamental niche of ponderosa pine forests [8].

Focusing solely on severe events may be at odds with the tendency for many ponderosa pine seedlings to die as a result of competition, frost heaving, and desiccation, 
which occur within the bounds of average environmental variability $[9,10]$. Climate and environmental conditions within the bounds of average variability-which we refer to as moderate variation - often induces mortality among regeneration cohorts in the first years following germination, limiting survival to the best situated individuals. Although low survivorship was sufficient to sustain tree populations historically [11,12], small declines in survival could severely limit persistence. Petrie et al. [2] predict that reduced frost heaving will increase favorability for regeneration in the near future, but favorability will decline later in the 21st century due to enhanced drought and higher air temperatures. Improved understanding of the growth characteristics of conifer seedlings and juveniles [13] and their stress tolerance in marginal and disturbed environments [5,14] suggest that Petrie et al. [2]'s forecasts may overestimate regeneration because their analysis was most attuned to severe changes in climate. That is, the capacity for moderate events to limit both natural and human-assisted regeneration is not yet incorporated into regeneration forecasts.

In the southern Intermountain region of the western US, ponderosa pine forests experience periods of above-average temperatures and low rainfall in spring prior to the onset of the summer monsoon, and again in early fall when monsoonal rainfall subsides [15]. Unlike the severe drought periods that have induced high adult pine mortality in this region [16,17], moderate seasonal dry periods are a regular occurrence in these forests and do not commonly induce stress to adult trees. During these seasonal dry periods, rainfall events are often small ( $\leq 5 \mathrm{~mm})$, relatively infrequent [18], and are the primary source of moisture recharge in shallow soil layers (0-30 cm depth; Koehn et al. [19]). Naturally growing ponderosa pine seedlings and juveniles have shallow rooting depths and do not acclimate growth to environmental variation [13], and it follows that moderate dry periods are an important component of tree thinning and tree survival [8,20]. Yet there has been little focus on the mechanisms of regeneration until recently [21], and there is need to further define the range of conditions under which seedlings can survive.

Conifer seedlings and juveniles are influenced by understory microclimates, access to moisture and light resources, and variation in stress tolerance at the species and population level [22,23]. Ponderosa pine seedlings have shown increased survival in sheltered microsites with high soil moisture availability [24,25]. However, Puhlick et al. [26] found that canopy cover did not have a significant effect on seedling density, and Pirtel et al. [13] observed that ponderosa pine juveniles-which require access to light-grew taller in unsheltered microsites. Additionally, the degree to which physiological differences among ponderosa pine subpopulations may shape their ability to upregulate photosynthesis following rainfall pulses and minimize water losses to evaporation is a component of regeneration success that is not well understood [27]. Hydraulic vulnerability varies between ponderosa pines of different ages ( 30-245 yr; Domec et al. [28]), and between trees growing in different environments $[29,30]$. The hydraulic vulnerability of young juveniles and seedlings remains unclear, although planted ponderosa pines may be more vulnerable than naturally growing trees that have experienced significant hardening to environmental stress and lower growth $[22,31]$. These studies illustrate uncertainty associated with the microclimate conditions and stress tolerance differences that support and limit ponderosa pine regeneration. In a changing climate, it is possible that the low moisture stress and high light conditions where these trees grow best will diverge, leading to novel and uncertain regeneration futures.

Increasing mortality of ponderosa pine seedlings during moderate dry periods may restrict the persistence of ponderosa pine forests in the western United States. In the Colorado Front Range, these periods are characterized by warm temperatures and elevated vapor pressure deficit, small and infrequent rainfall events, and low near-surface soil moisture [15]. There is need to elucidate how precipitation patterns, microsite conditions, and population level responses shape planted ponderosa pine seedling functioning and survival during these periods. We conducted a controlled field experiment to ascertain how variation in small rainfall events during an experimentally-induced 45-day moderate dry period influenced the hydraulic functioning and inferred mortality and survival of 
3 populations of year-old potted in-ground ponderosa pines, which were located in high and low canopy cover microsites. Our primary objective was to determine if seedlings utilized moisture from small rainfall events to survive moderate dry periods. Our secondary objectives were to: (a) evaluate the impact of small rainfall treatments on near-surface soil moisture and seedling water utilization; (b) characterize the abiotic properties of shaded and unshaded microsites during moderate dry periods; (c) quantify how seedling transpiration differed across rainfall treatments; and (d) to attribute seedling hydraulic functioning and inferred mortality to experimental treatments and microsite conditions. We hypothesized that measures of tree hydraulic functioning and survival would be highest for groups receiving larger rainfall pulses, and that inferred survival would be higher in shaded compared to unshaded microsites.

\section{Methods}

\subsection{Site Description}

The Colorado Front Range-located along the eastern edge of the Rocky Mountains in the southern Intermountain region of the western United States-supports ponderosa pine-dominated forests, many of which are located on government managed lands. Historically, these forests were open woodland with scattered trees and open, grass-dominated understories [32]. Following extensive logging in the 1800s, these forests regenerated to have higher tree and canopy densities due to human fire suppression [32]. The Front Range experiences moderate warm and dry periods in late spring following snowmelt depletion and prior to the onset of higher summer precipitation, and also in the late summer after high rainfall periods have subsided (Figure 1; Notaro et al. [15]). Distinct populations and haplotypes of ponderosa pine are found across the Intermountain region [33], but it is not yet clear to what degree differences in the physiology and stress tolerance of these subpopulations may influence forest regeneration and persistence [31,34]. We conducted our study at the USDA Forest Service Manitou Experimental Forest in the Colorado Front Range (MEF; Figure 1, Supplementary Table S1). This forest has been managed since 1936 to study range management, human-assisted regeneration, and watershed management [35]. Our experimental site was located in a ponderosa pine forest and nearby $(<200 \mathrm{~m}$ distance) meadow opening at an elevation of $2383 \mathrm{~m}\left(39.101103^{\circ} \mathrm{N}\right.$ latitude, $105.105259^{\circ} \mathrm{W}$ longitude). The ponderosa pine location had been thinned to a moderate basal area density $\left(22-24 \mathrm{~m}^{-2} \mathrm{ha}^{-1}\right)$, which is lower than unmanaged basal area densities of $20-40 \mathrm{~m}^{-2} \mathrm{ha}^{-1}$ found across the larger Intermountain region [13]. At the study site, prevailing winds from the west and south limited edge effects of the meadow to the north. Soils in both experimental sites were classified as gravelly sandy loam $(0-30 \mathrm{~cm}$; [36]), and partially shaded environments in both the forest and meadow supported a high level of natural ponderosa pine regeneration. Based on MEF weather station data from 1950-2018, mean monthly high temperatures at MEF ranged from $6.7^{\circ} \mathrm{C}$ (January) to $26.8^{\circ} \mathrm{C}$ (July). Estimated from PRISM from 1978-2018 [37], mean monthly rainfall totals range from $18.6 \mathrm{~mm}$ (January) to $87.3 \mathrm{~mm}$ (August), with a mean annual rainfall total of $570.1 \mathrm{~mm}$ (Figure 1). Nearly half of annual precipitation falls during the summer (June to August), in many cases associated with the North American Monsoon System. The elevation and climate of MEF is consistent with that of ponderosa pine forests in the southern Intermountain region of the western United States, although MEF has sandier soils than are found in other locations [2,13].

\subsection{Experimental Design and Implementation}

We obtained 290 ponderosa pine seedlings grown from seed in 2019-2020 at an outdoor facility at the USDA Forest Service Charles E. Bessey Tree Nursery in Halsey, Nebraska, USA. Seed were sourced from 3 Colorado subpopulations: Arapaho-Roosevelt National Forests (AR; Seedlot PIPO-10-05-491-0720-09; 102 individuals), Pike and San Isabel National Forests (PS; Seedlot PIPO-12-11-494-0760-11; 102 individuals), and San Juan-Rio Grande National Forests (SR; Seedlot PIPO-13-05-247-0720-15; 86 individuals; Supplementary Table S1, Figure 1). Trees were germinated in October, 2019, and grown outdoors in 
containerized styrofoam by USFS personnel (Styro-block 112, Stuewe \& Sons, Inc., Tangent, OR, USA). Upon the initiation of our experiment in August, 2020, seedlings were 10 months old, which corresponds to juvenile tree age entering their first full summer following previous-year germination. During a 45-day period in August-October, 2020, we employed a fully-crossed experimental manipulation of precipitation timing · precipitation magnitude between partially shaded and unshaded environmental microsites. The partially shaded microsite was located within the forest canopy in an area with existing ponderosa pine regeneration ( $47 \%$ canopy cover), whereas the nearby unshaded microsite was in an open, grass-dominated area with no overstory and no regeneration ( $1 \%$ canopy cover).
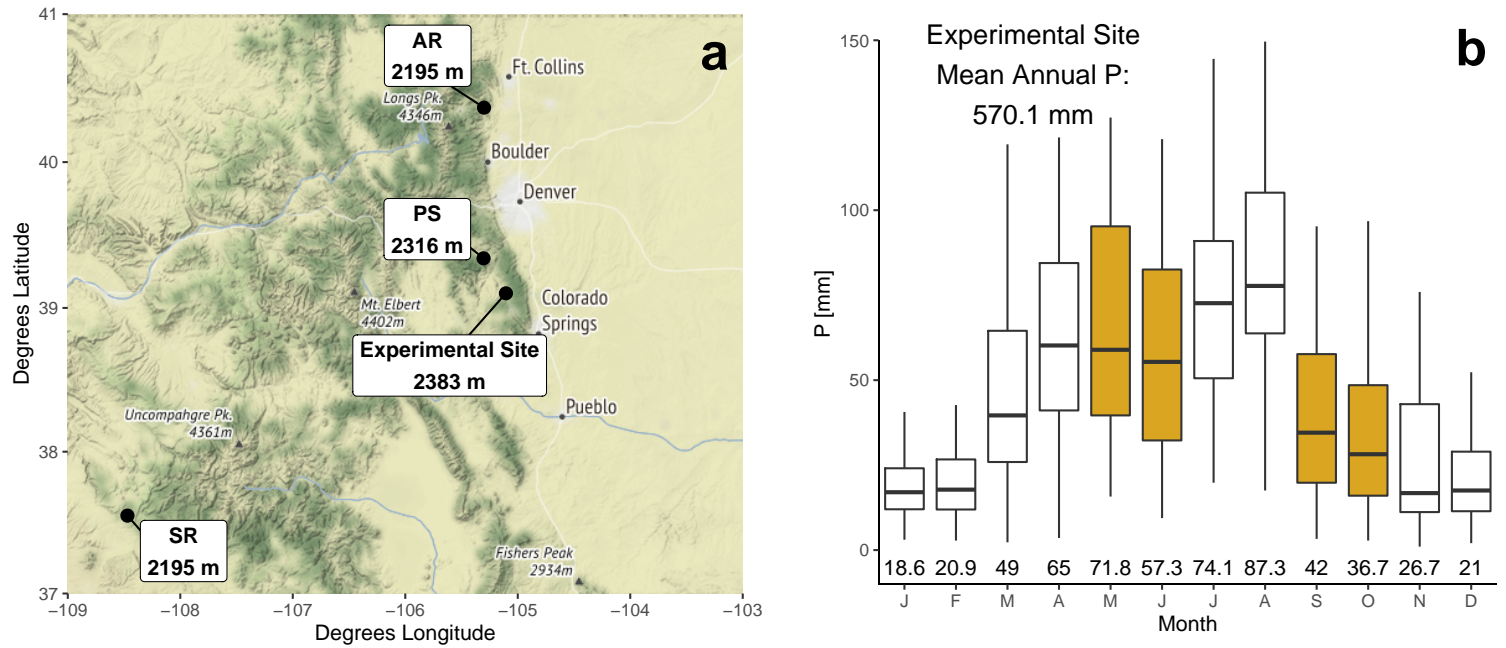

Figure 1. Map of seed sources (AR: Arapaho-Roosevelt National Forests, PS: Pike \& San Isabel National Forests, and SR: San Juan-Rio Grande National Forests) and study site (Manitou Experimental Forest) in Colorado (Panel (a)), and boxplots of monthly precipitation totals at the Manitou Experimental Forest from 1978-2018, estimated from PRISM (PRISM Climate Group at Oregon State University [37]; Panel (b)). In Panel (b), estimates of mean monthly precipitation are shown for each month, and months used to design precipitation treatments for this study (using both PRISM estimates and meteorological data) are highlighted.

Treatments were conducted under complete rain-out shelters, constructed using 90\% transmission SUNTUF panels. High wind mixing in sheltered and unsheltered microsites minimized microclimate impact of the shelters. Fences were constructed around shelters to prevent herbivory, which did not occur during the experiment. Trees were planted in $9 \times 23 \mathrm{~cm}$ pots (MT39, Stuewe \& Sons, Inc., Tangent, OR, USA) and included the soil media trees were growing in. Soil from the top $30 \mathrm{~cm}$ of the soil profile was mixed and used to fill the pots. The experimental pot size completely enveloped the root profile $(\mathrm{ca} .3 \times 20 \mathrm{~cm}$ ) at all times during the experiment, and the percolation water addition treatments was not influenced by the sides of the tree pots. Pots were located in back-filled holes to minimize unnatural soil heating. We acclimated planted trees for 7 days prior to the onset of the experiment, and did not observe signs of tree stress (needle browning, wilting) during the acclimation period. The experiment was conducted from 17 August to 30 September 2020.

\subsection{Rainfall Treatments}

We developed watering treatments from daily precipitation at MEF, specifically focusing on the two moderate seasonal dry periods that this location experiences in early summer (May-June) and early fall (September-October; Figure 1). To develop rainfall treatments we used a statistical framework described in Petrie et al. [38]. Precipitation events $<3.56 \mathrm{~mm}_{\text {day }}{ }^{-1}$ during warm and dry months (May, June, September, October) did not significantly reduce total monthly precipitation when removed from the precipitation record (paired $t$-test, $p<0.05$ ), yet constitute $91 \%$ of rainfall events during these months. 
We replicated a realistic application of rainfall timing within a 45 day period by modeling our treatment timing after observed rainfall at MEF from 1 May through 14 June 2006, which characterized the average rainfall pattern of dry periods at this location and was a natural analog of the watering pattern expected to progressively induce stress to conifer seedlings. Rainfall additions were more frequent at the beginning of the 2006 dry period and less frequent towards the end.

Data from the MEF meteorological station (1950-2018) were lower than precipitation estimates from PRISM (1978-2018; Figure S1). On average, 45-day periods at MEF in May-June experienced $67 \mathrm{~mm}$ (MEF data) and $95 \mathrm{~mm}$ (PRISM estimates) of precipitation, and in September-October 45-day periods experienced $36 \mathrm{~mm}$ (MEF data) and $58 \mathrm{~mm}$ (PRISM estimates). Our rainfall treatments ranged from a total of $24 \mathrm{~mm}$ to $54 \mathrm{~mm}$. These treatments roughly correspond to a period with 33-71\% lower precipitation than average in May-June, and from 49\% lower to 15\% higher than average in September-October. This range of treatments falls within observed variability in seasonal precipitation at MEF, but we note that these treatments are estimations of the pattern and magnitude of in situ rainfall experienced during moderately dry periods.

Precipitation treatments included no rain (NR), an average rainfall period constituted of only small rainfall events constructed from a 45-day dry period in 2006 (Control: C), an average year with $+50 \%$ rainfall events (Timing: $\mathrm{T}$ ), an average period with $+50 \%$ rainfall event magnitude (Magnitude: $M$ ), and an average period with $+50 \%$ rainfall events and $+50 \%$ rainfall event magnitude (Timing \& Magnitude: TM). Our control (C) treatment corresponded to the average number and magnitude of small rainfall events during 45-day moderate dry periods at MEF (24 mm total rainfall), and the TM treatment corresponded to slightly below average rainfall $(54 \mathrm{~mm})$, but delivered entirely as small rainfall events. There were 34 ponderosa pine individuals in each precipitation · microsite treatment with the exception of NR ( 9 trees in each microsite). Trees from each subpopulation were distributed evenly across treatments (12 AR, 12 PS, 10 SR in each).

Our treatments of average timing $(C, M)$ and $+50 \%$ timing $(T, T M)$ constituted 4 and 6 rainfall events, respectively. Because shading and reduced vapor pressure deficit that occurs during a natural rainfall event is often absent when watering treatments are applied, we increased our average small event from $3.56 \mathrm{~mm}$ to $4 \mathrm{~mm}$ for treatment groups with average rainfall magnitude $(C, T$; based on analysis of potential evapotranspiration rates from unpublished data). Groups receiving 50\% more water (M, TM) during simulated rainfall events received $6 \mathrm{~mm}$ of water per event. Watering treatments were applied directly to the soil at the base of each tree in the morning of each watering day.

\subsection{Climate and Environmental Characteristics}

Air temperature [Ta: ${ }^{\circ} \mathrm{C}$ ] and relative humidity [RH: \%] were measured under solar radiation shields at $1 \mathrm{~m}$ height within the shaded and unshaded microsites using an air temperature and relative humidity sensor (1 sensor in each site; Campbell Scientific EE-181, Campbell Scientific, Logan, UT, USA). The average density of photosynthetically active radiation [PAR: $\mu \mathrm{mol} \mathrm{s} \mathrm{m}^{-1} \mathrm{~m}^{-2}$ ] was measured at $1 \mathrm{~m}$ height using a quantum sensor (1 sensor in each site; Campbell Scientific CS-310, Apogee Instruments, Logan, UT, USA). At the unshaded site, solar radiation [S: $\mathrm{W} \mathrm{m}^{-2}$ ] was measured at $2 \mathrm{~m}$ height using a digital thermopile pyranometer (Campbell Scientific CS-320, Campbell Scientific, Logan, UT, USA) and wind speed [u: $\mathrm{m} \mathrm{s}^{-1}$ ] and direction was measured at $2 \mathrm{~m}$ height using a wind monitor (Campbell Scientific 05103, R.M. Young, Traverse City, MI, USA).

The canopy temperature [Tc: ${ }^{\circ} \mathrm{C}$ ] of each microsite-treatment group (excepting treatment NR) was measured using infrared radiometers (Campbell Scientific SI-111SS, Apogee Instruments, Logan, UT, USA) positioned above tree groups to measure the center twothirds of the canopy area. Volumetric soil moisture [VWC: $\mathrm{mm}^{3} \mathrm{~mm}^{-3}$ ] was measured at $5 \mathrm{~cm}$ and $12 \mathrm{~cm}$ for two trees in each microsite-treatment group, and for one tree for shaded and unshaded NR (18 total trees) using soil moisture probes (TEROS-10, METER Group, Pullman, WA, USA) inserted through the side of the pot centered on $5 \mathrm{~cm}$ and $12 \mathrm{~cm}$ from 
the soil surface. The edges of the soil moisture probe housing were sealed against tree pots to prevent water loss. Soil surface temperature [Ts: $\left.{ }^{\circ} \mathrm{C}\right]$ was measured for one tree in each microsite-treatment group (10 total trees) using temperature probes (Campbell Scientific T-109, Campbell Scientific, Logan, UT, USA) inserted into the top $0-5 \mathrm{~cm}$ of soil. All sensor measurements were collected at 15 min intervals.

\subsection{Seedling Transpiration, Stress, and Inferred Mortality}

To assess seedling response to watering treatments, we made daily observations of needle browning (\% needles browned), as well as tree transpiration measured as grams water transpired per leaf area [transpiration: $\mathrm{g} \cdot \mathrm{mm}^{-2}$ ] on and following watering days (assessed at 3, 6, 9, 24, and $48 \mathrm{~h}$ after small rainfall application for 4 trees in each treatment). Leaf area was measured in the lab following the conclusion of the experiment, and was corrected for loss of area due to needle browning. The bottom of tree pots used for transpiration measurements were sealed to prevent loss of water or soil. Following watering, the top of the pot was covered with brown closed-cell foam to prevent evaporation. Trees were weighed at $0,3,6,9,24$, and $48 \mathrm{~h}$ after watering. The difference between initial weight after watering and later weight was limited to water losses via tree transpiration.

Following the conclusion of the experiment we evaluated the relative water loss [RWL: \%] of experimental trees. RWL is a measure of conduit water loss that captures variation in cavitation [39], and we calculated RWL using the methodology of Hietz et al. [40]. Specifically, we removed tree needles and cut the stem at the root crown. Terminal buds were severed and the base of the cutting was de-barked. The cutting was weighed to find its fresh weight [FW: g] and then submerged in purified water containing $0.005 \%(v / v)$ Micropur (Katadyn Produkte AG, Wallisellen, Switzerland) to prevent microbial growth. Submerged cuttings were subjected to partial vacuum (ca. 10-25 kPa) until they sunk (ca. 24 h). Each cutting was removed from the water, blotted dry, and weighed to find its saturated weight [SW: g]. Cuttings were then dried for three days at $30^{\circ} \mathrm{C}$ and weighed again to find their dry weight [DW: g]. We then calculated RWL from Hietz et al. [40] as:

$$
R W L(\%)=(1-(F W-D W) /(S W-D W)) \cdot 100
$$

We then used the relationship between RWL and loss of hydraulic conductivity from Rosner et al. [41] to infer seedling mortality. Rosner et al. [41] determined RWL from sapwood area hydraulic conductivity under a hydraulic pressure head, and found a robust relationship $\left(R^{2}=0.99\right)$ between RWL and hydraulic conductivity for ponderosa pines. By comparing their analysis to the relationship of p50 and p88 values (representing $50 \%$ and $88 \%$ hydraulic conductivity loss, respectively; [42]), Rosner et al. [41] developed estimates of the range of RWL that correspond p50 and p88 of ponderosa pine seedlings. We present calculated p50 and p88 for our experimental trees as inferences of tree survival and mortality.

\subsection{Statistical Analysis}

Significant differences between treatment groups, microsites, and subpopulations were found using ANOVA and Tukey's honest significant difference tests. All analyses were conducted in $\mathrm{R}$ [43]. We used linear regression to determine significant environmental and treatment history effects on total 24 -h tree transpiration on and following watering days. We tested the effects of explanatory variables including 5 and $12 \mathrm{~cm}$ VWC (estimated from trees equipped with sensors in the same microsite-treatment group), VPD, PAR, Tc, Ts (estimated from trees equipped with sensors in the same microsite-treatment group), microsite, and treatment group. We tested explanatory variables in two types of models: direct effects only (VWC at $5 \mathrm{~cm}$ and $12 \mathrm{~cm}$, VPD, PAR, Tc, Ts) and direct plus treatment group. Direct effects capture transpiration response to environmental variables during each measurement period, whereas treatment group may also capture the legacy of experimental treatments. We tested the effects of explanatory variables over different experimental treatment groups and time periods: all trees across 45 days, shaded and unshaded microsites across 45 days, 
and shaded and unshaded microsites during the beginning (days 3-8) and middle (days 13-30) of the experiment. To select significant model terms, we first removed collinear terms, then used the function dredge from R package MuMIn [44] to perform AIC analysis on all combinations of each full model. We chose the model based on parsimony, within 3 AIC units of the top model with the fewest number of explanatory variables.

\section{Results}

\subsection{Experimental Environments}

Shaded and unshaded microsites experienced both statistically similar and different environmental conditions over the course of the experiment. Unshaded microsites experienced higher average daytime PAR and Ts compared to shaded sites (Table 1, Supplementary Figure S1b,d), whereas average daytime Ta and VPD did not vary significantly between them (Table 1, Supplementary Figure S1a,c). Unshaded microsites had higher daytime Tc, and in contrast shaded microsites had higher nighttime Tc (Table 1). Unshaded microsites had higher $5 \mathrm{~cm}$ and $12 \mathrm{~cm}$ VWC earlier in the experiment (days 1-12), and shaded microsites had significantly higher $5 \mathrm{~cm}$ and $12 \mathrm{~cm}$ VWC later in the experiment (days 13-45; $p<0.05$; Table 1 ).

VWC declined during the experiment and varied in response to watering (Figure 2). VWC at $5 \mathrm{~cm}$ increased in response to watering, but VWC at $12 \mathrm{~cm}$ only increased in TM treatments. Consequentially, VWC at $5 \mathrm{~cm}$ decreased at a higher rate than at $12 \mathrm{~cm}-$ average VWC at $5 \mathrm{~cm}$ declined to 0.05 by day 23 of the experiment, whereas at $12 \mathrm{~cm}$ it did not decline to 0.05 until day 37 (Figure 2). By the end of the experiment, unshaded sites had significantly lower VWC than shaded sites (Figure 2, Table 1). VWC in each treatment . microsite group was generally significantly different from all others, illustrating the varied effect of experimental treatments (Table 1).
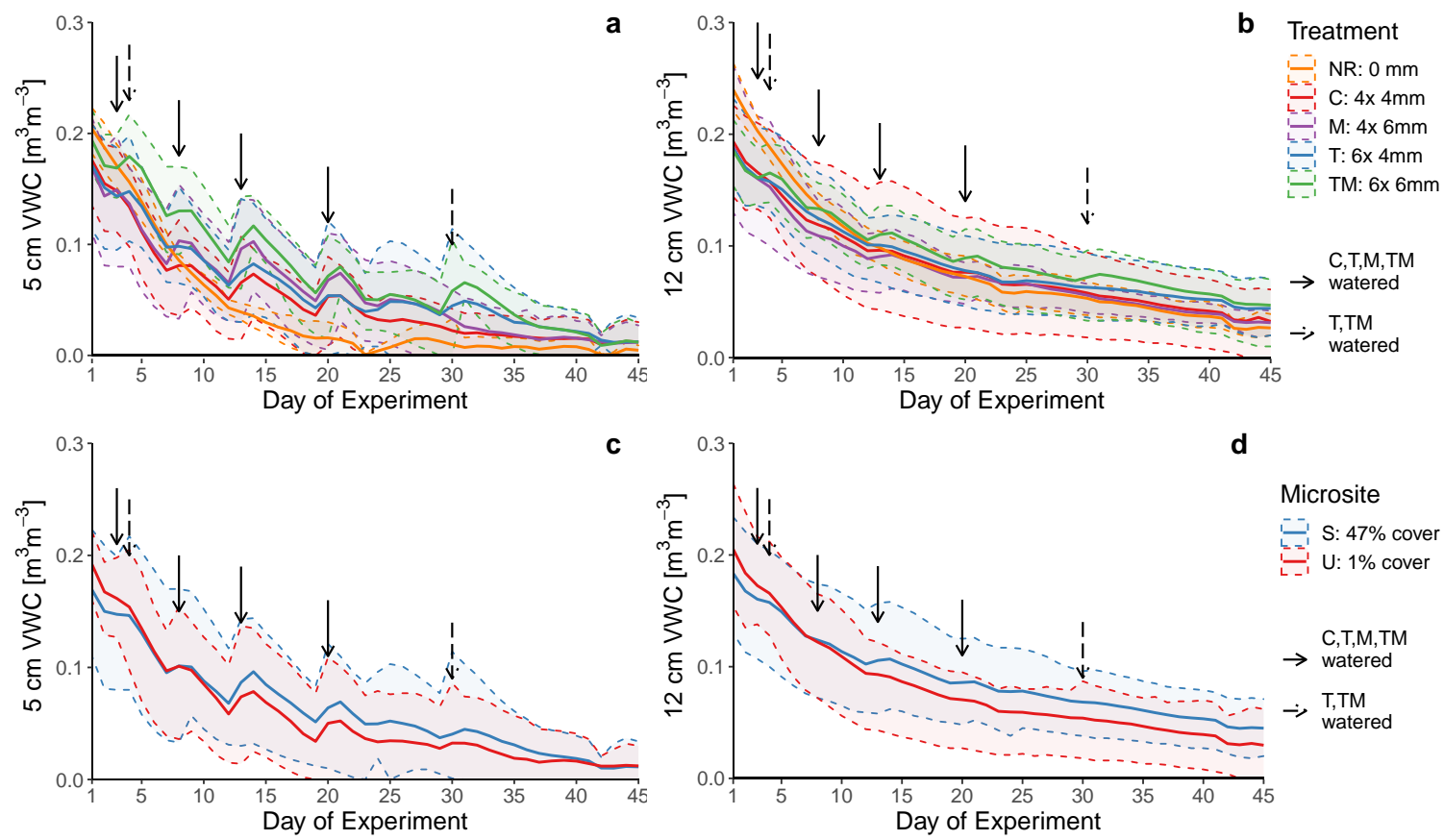

Figure 2. Timeseries of volumetric soil water content [VWC: $\mathrm{m}^{3} \mathrm{~m}^{-3}$ ] from Day 1 through Day 45 of the experiment (15 August 2020-30 September 2020) by treatment (NR: no rain, C: control (4 events; $4 \mathrm{~mm}$ per event), M: $+50 \%$ magnitude ( 4 events; $6 \mathrm{~mm}$ per event), T: $+50 \%$ timing ( 6 events; $4 \mathrm{~mm}$ per event), and TM: $+50 \%$ timing and magnitude ( 6 events; $6 \mathrm{~mm}$ per event); Panels $(\mathbf{a}, \mathbf{b}))$, microsite (shaded: S and unshaded: U; Panels $(\mathbf{c}, \mathbf{d}))$, and soil depth $(5 \mathrm{~cm}$ : panels $(\mathbf{a}, \mathbf{c}) ; 12 \mathrm{~cm}$ : panels $(\mathbf{b}, \mathbf{d}))$. Lines indicate daily mean VWC and shaded areas indicate the daily range of recorded VWC. Arrows indicate watering treatment days, with solid arrows indicating a day when groups C, M, T, and TM were watered and dashed arrows indicating days when only groups T and TM were watered. 
Table 1. Summary of experimental water addition treatments and environmental characteristics of treatment groups (NR: no rain, C: control, M: $+50 \%$ magnitude, $\mathrm{T}:$ $+50 \%$ timing, TM: $+50 \%$ timing and magnitude) within microsites (shaded: $47 \%$ canopy cover, unshaded: $1 \%$ canopy cover). Soil moisture [VWC: $\mathrm{mm}^{3} \mathrm{~mm}^{-3}$ ] is organized between $5 \mathrm{~cm}$ and $12 \mathrm{~cm}$ depths and periods of treatment days before (days 1-12) and after (13-45) when VWC began to be depleted (see Figure 3). Because shelter t treatment period VWC differences were significant but very small, arrows indicate which group was significantly higher or lower in each column. Letters indicate statistically significant differences within the 10 shelter-treatment subgroups, and stars indicate statistically significant groupings between sheltered and unsheltered microsites, determined by ANOVA and Tukey's honest significant differences $(p<0.05)$. Daytime values were 8:00-20:00, and nighttime canopy temperature was 4:00-6:00. Significant differences found using Tukey's honest significant differences $(p<0.05)$.

\begin{tabular}{|c|c|c|c|c|c|c|c|c|c|c|c|c|}
\hline & $\begin{array}{c}\text { Number of } \\
\text { Events }\end{array}$ & $\begin{array}{c}\text { Total P } \\
\text { (mm) }\end{array}$ & $\begin{array}{c}5 \mathrm{~cm} \bar{\theta} \\
\text { (Days 1-12) }\end{array}$ & $\begin{array}{c}12 \mathrm{~cm} \bar{\theta} \\
\text { (Days 1-12) }\end{array}$ & $\begin{array}{l}5 \mathrm{~cm} \bar{\theta} \\
\text { (Days } \\
13-45 \text { ) }\end{array}$ & $\begin{array}{c}12 \mathrm{~cm} \bar{\theta} \\
\text { (Days } \\
13-45 \text { ) }\end{array}$ & $\begin{array}{c}\text { Daytime Air } \\
\text { Temp }\left({ }^{\circ} \mathrm{C}\right)\end{array}$ & $\begin{array}{l}\text { Daytime } \\
\text { Soil Temp } \\
\left({ }^{\circ} \mathrm{C}\right)\end{array}$ & $\begin{array}{c}\text { Daytime } \\
\text { Canopy } \\
\text { Temp }\left({ }^{\circ} \mathrm{C}\right)\end{array}$ & $\begin{array}{c}\text { Night } \\
\text { Canopy } \\
\text { Temp }\left({ }^{\circ} \mathrm{C}\right)\end{array}$ & $\begin{array}{c}\text { Daytime PAR } \\
(\mu \mathrm{mol} \\
\left.\mathrm{s}^{-1} \mathrm{~m}^{-2}\right)\end{array}$ & $\begin{array}{c}\text { Daytime } \\
\text { VPD (kPa) }\end{array}$ \\
\hline Shaded & & & $0.12 \downarrow$ & $0.14 \downarrow$ & $0.05 \uparrow$ & $0.07 \uparrow$ & 18.95 & $17.38^{*}$ & $19.53 *$ & 5.54 * & $354 *$ & 1.76 \\
\hline C & 4 & 16 & $0.10^{j}$ & $0.15^{d}$ & $0.03^{t}$ & $0.07^{m}$ & & $19.67^{e}$ & $20.67^{c}$ & $6.06^{a}$ & & \\
\hline M & 4 & 24 & $0.10^{k}$ & $0.10^{j}$ & $0.05^{q r}$ & $0.06^{p}$ & & $17.30^{f}$ & $19.26^{d}$ & $5.43^{a b}$ & & \\
\hline $\mathrm{T}$ & 6 & 24 & $0.12^{i}$ & $0.13^{f}$ & $0.06^{p}$ & $0.06^{m}$ & & $16.89 f g$ & $19.81^{d}$ & $5.61^{a}$ & & \\
\hline $\mathrm{TM}$ & 6 & 36 & $0.15^{d}$ & $0.16^{b}$ & $0.06^{p}$ & $0.09^{l}$ & & $16.49 g$ & $19.24^{d}$ & $5.75^{a}$ & & \\
\hline Unshaded & & & $0.12 \uparrow$ & $0.14 \uparrow$ & $0.04 \downarrow$ & $0.06 \downarrow$ & 19.26 & 21.94 * & $22.84^{*}$ & 4.11 * & $741 *$ & 1.80 \\
\hline NR & 0 & 0 & $0.11^{i}$ & $0.17^{a}$ & $0.01^{v}$ & $0.06^{n}$ & & $21.10^{c d}$ & & & & \\
\hline C & 4 & 16 & $0.10^{j}$ & $0.12 g h$ & $0.03^{t}$ & $0.05^{r s}$ & & $20.71^{d}$ & $23.50^{a}$ & $4.65^{b c}$ & & \\
\hline $\mathrm{M}$ & 4 & 24 & $0.12^{g h}$ & $0.15^{c}$ & $0.04^{s}$ & $0.06^{\circ}$ & & $23.27^{b}$ & $23.61^{a}$ & $4.05^{c}$ & & \\
\hline $\mathrm{T}$ & 6 & 24 & $0.11^{i}$ & $0.15^{d}$ & $0.02^{u}$ & $0.06^{p}$ & & $21.37^{c}$ & $22.50^{b}$ & $4.41^{c}$ & & \\
\hline $\mathrm{TM}$ & 6 & 36 & $0.14^{e}$ & $0.13^{g}$ & $0.05^{q}$ & $0.06^{p}$ & & $23.95^{a}$ & $22.89^{a b}$ & $4.06^{c}$ & & \\
\hline
\end{tabular}




\subsection{Seedling Transpiration}

Although seedlings increased transpiration rates after watering (Figure 3a), transpiration declined throughout the experiment, likely in response to both declining VWC and increasing tree stress. Transpiration was significantly higher early in the experiment (days $3-8$ ), and was not significantly different between days $13-30$ and day 45 (Figure 3b,d). TM trees had significantly higher transpiration compared to other treatment groups (Figure $3 b$ ). Unshaded trees, which were exposed to higher PAR (Supplementary Figure S1d), had significantly higher transpiration at the beginning of the experiment when VWC was high, but did not transpire at a higher rate than shaded trees later in the experiment (Figure 3c). We found no significant differences in transpiration among Colorado subpopulations of ponderosa pine (Figure 3d).
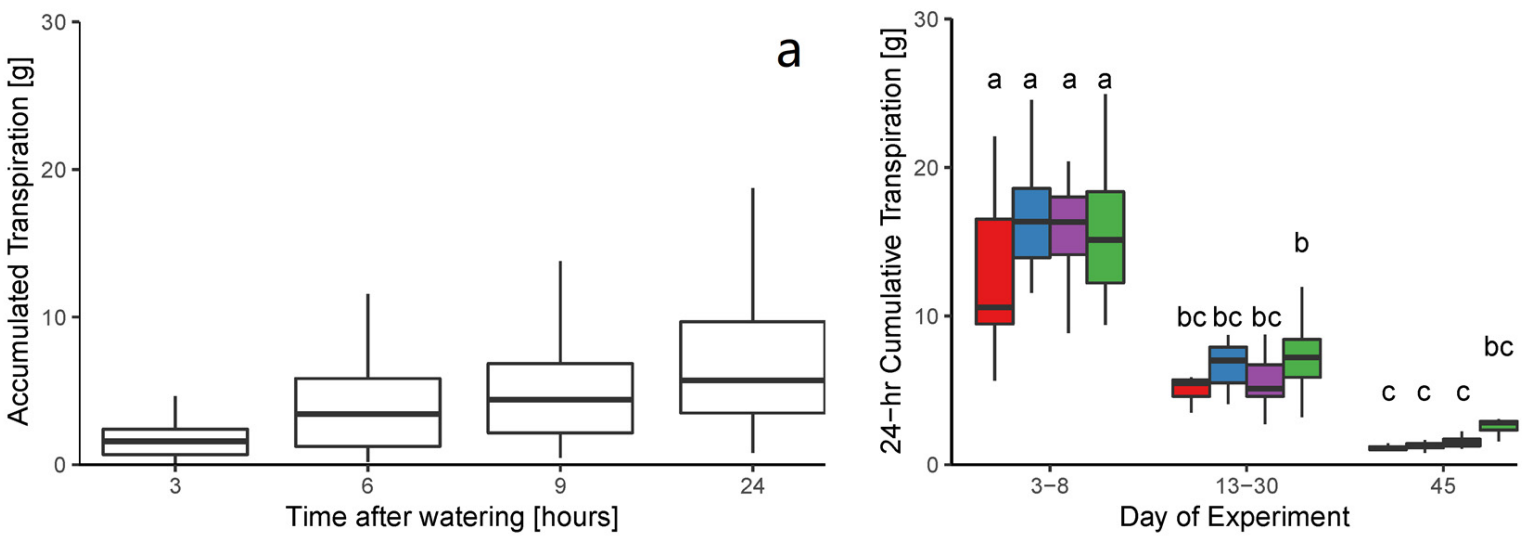

b
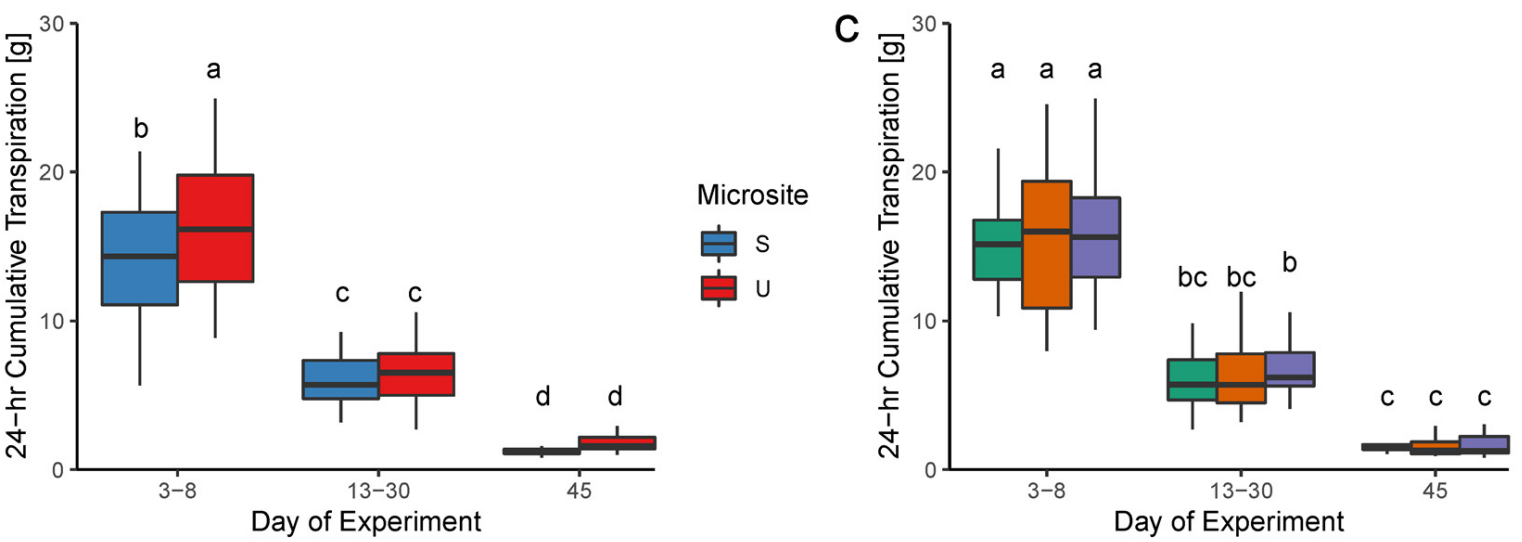

d

Population

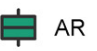

PS

它 SR

Figure 3. Total accumulated transpiration [g] averaged over 3-24 h time periods (Panel (a)) following water addition treatments, and cumulative 24-h transpiration following water addition treatments compared across different successively drier periods within the 45-day experiment for water addition treatments (Panel (b)), shaded (S) and unshaded (U) microsites (Panel (c)), and ponderosa pine subpopulations (Panel (d)). Letters indicate statistically significant groupings within each panel, determined by ANOVA and Tukey's honest significant differences $(p<0.05)$.

Over the 45 day experiment, VWC at $5 \mathrm{~cm}$ and VPD were significant explanatory variables for transpiration, and the addition of treatment group moderately increased explanatory power ( $R^{2}$ increase of 0.044 ; Supplementary Tables S2 and S3). Transpiration at unshaded sites was more influenced by $12 \mathrm{~cm}$ VWC than $5 \mathrm{~cm}$ VWC (Supplementary Table S4). Models for transpiration early in the experiment (days 3-8) found that Ts, VPD and VWC were top explanatory variables, whereas later in the experiment (days 13-30) treatment history were the top variables (Supplementary Tables S3 and S4). This corroborates observed Ta and Tc differences between treatment groups, which captures the degree to which transpiration increases latent energy exchange and results in canopy cooling. Early in the experiment (days 1-10), transpiration resulted in canopy cooling 
and cooling was most apparent following watering treatments (Figure 4). Based on Tc cooling responses following watering later in the experiment, we estimate a severe decline in hydraulic functioning for treatment group $C$ trees in days 20-30, followed by severe declines for treatment group M, T and TM trees in days 30-45 (Tc measurements were not available for unshaded $M$ trees due to sensor error; Figure 4). We caution against further interpretation of the magnitude of Tc-Ta, especially across experimental time periods, due to differences in Ta and atmospheric demand during the experimental period.

Shaded

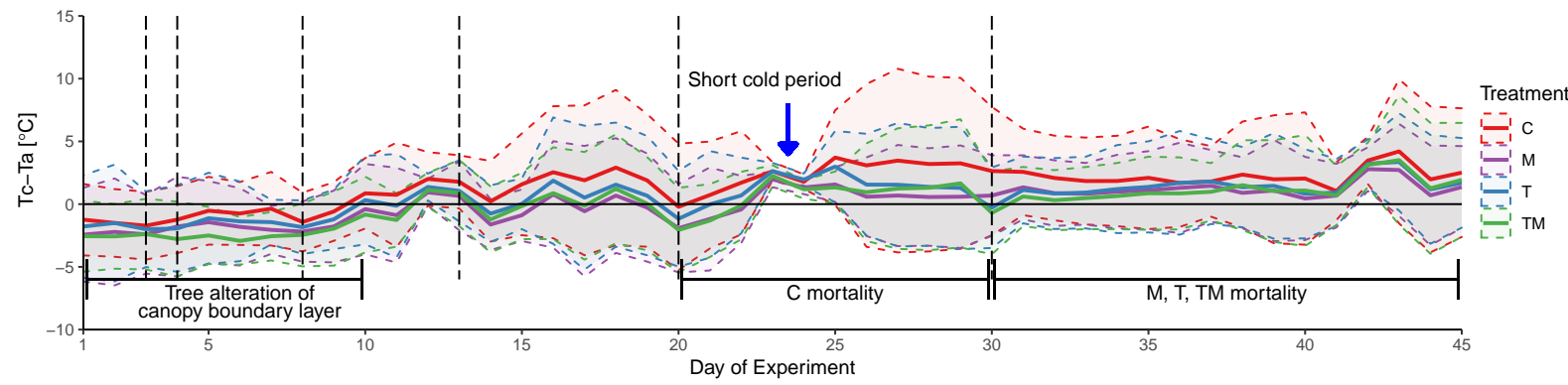

Unshaded

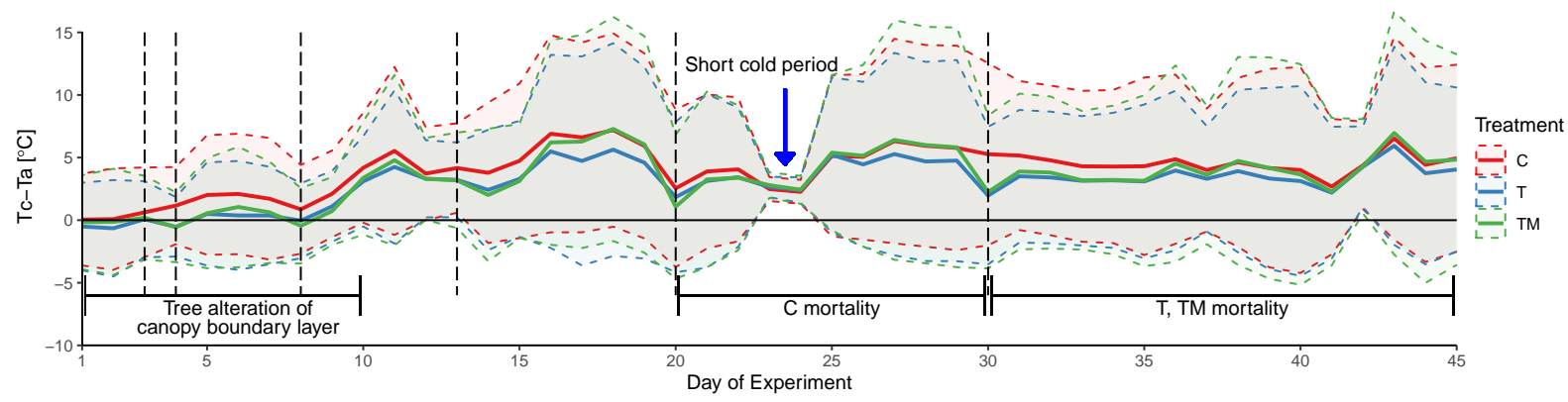

Figure 4. Daily means of the daytime (8 a.m.-8 p.m.) difference between seedling canopy temperature and ambient air temperature (canopy minus ambient) across treatment groups for shaded (Panel (a)) and unshaded (Panel (b)) microsites. Negative values indicate days where seedling canopy temperature was lower than ambient air temperature, and variation in these values is presumed to be the consequence of variation in latent energy exchange via transpiration within tree canopies. Dashed lines indicate watering days. Shading illustrates \pm 1 standard deviation about daily mean values. Contraction of standard deviations occurred on two days during a short cold event (indicated by an arrow). Values for treatments of higher magnitude (treatment $M$ ) in unshaded microsites are not shown due to sensor error.

\subsection{Stress and Mortality}

Treatment groups NR and C had significantly higher RWL compared to other treatment groups (Figure 5a). We did not find significant differences in RWL among ponderosa pine subpopulations (Figure 5b), although subpopulation SR (San Juan-Rio Grande) had higher needle browning compared to subpopulations AR and PS (Supplementary Figure S2). Average needle browning at the end of the experiment was significantly higher for unshaded trees (Table 2, Supplementary Figure S2). Rosner et al. [41] report that juvenile ponderosa stems reach p50 when RWL $=30.13 \%$. Only 3 trees out of 290 total $(1 \%)$ had RWL values lower than the p50 level at the end of the experiment (Figure 6a, Tables 2 and 3). At the p88 level, inferred survival remained very low (Figure 6). 

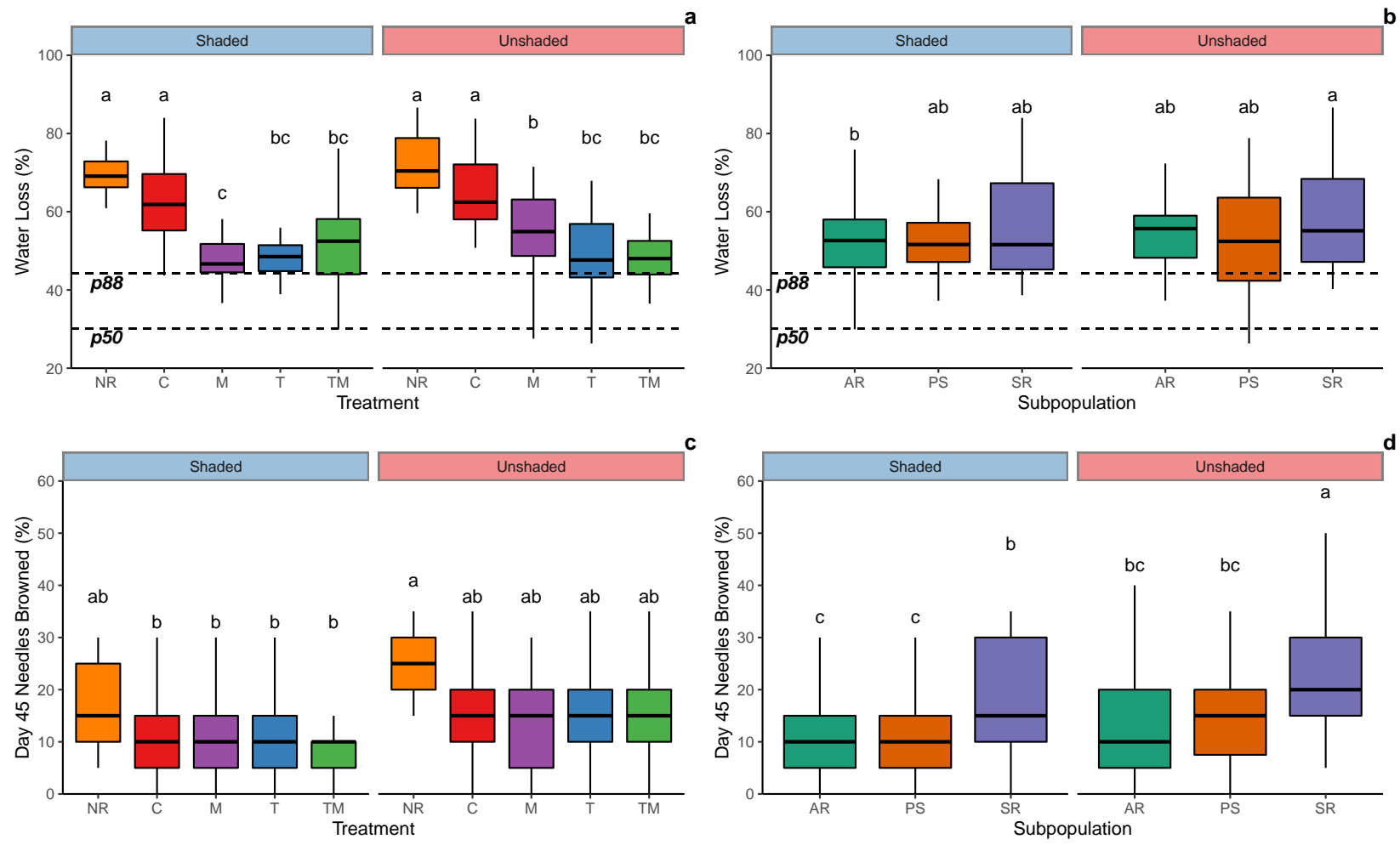

Figure 5. Relative water loss [RWL: \% xylem conduits cavitated] among treatment groups in shaded and unshaded microsites (Panel (a)), relative water loss among subpopulations in shaded and unshaded microsites (Panel (b)), needles browned on the last experiment day among treatmentmicrosite groups (Panel (c)), and needles browned among subpopulation-microsite groups (Panel (d)). In Panels a and b, p50 and p88 refer to 50\% and 88\% loss of conductivity, respectively, inferred through relative water loss [41]. Letters indicate statistically significant groupings in each panel, determined by ANOVA and Tukey's honest significant differences $(p<0.05)$.

Table 2. Average needle browning [\%], 24-h transpiration following watering treatments [g], relative water loss at the end of the experiment [RWL: \%], and number of trees with RWL below the p50 value for experimental treatment groups (NR: no rain, C: control, M: $+50 \%$ event magnitude, T: $+50 \%$ timing, TM: $+50 \%$ timing and magnitude) in shaded (47\% canopy cover) and unshaded ( $1 \%$ canopy cover) microsites. Letters indicate statistically significant differences within the 10 shelter-treatment subgroups, and stars indicate statistically significant groupings between sheltered and unsheltered microsites, determined by ANOVA and Tukey's honest significant differences $(p<0.05)$.

\begin{tabular}{|c|c|c|c|c|c|c|c|}
\hline & \multicolumn{2}{|c|}{ Needle Browning [avg \%] } & \multicolumn{3}{|c|}{ 24-h Transpiration $[g]$} & \multirow[b]{2}{*}{ RWL [avg \%] } & \multirow[b]{2}{*}{ Trees $\mathrm{RWL}<\mathrm{p} 50$} \\
\hline & Day 12 & Day 45 & Days 3-8 & Days $13-30$ & Day 45 & & \\
\hline Shaded & 5.42 & $11.97 *$ & 14.27 * & 6.02 & 1.45 & 53.6 & 1 \\
\hline NR & $7.78^{b c}$ & $17.22^{a b}$ & - & - & - & $69.5^{a}$ & 0 \\
\hline C & $5.15^{b c}$ & $12.06^{a b}$ & $10.43^{b c}$ & $5.37^{c d}$ & $1.03^{d}$ & $62.9^{a}$ & 0 \\
\hline M & $6.47^{b c}$ & $12.79^{a b}$ & $16.67^{a}$ & $6.30^{c d}$ & $1.07^{d}$ & $47.0^{c}$ & 0 \\
\hline $\mathrm{T}$ & $6.32^{b c}$ & $12.50^{a b}$ & $16.37^{a}$ & $5.13^{d}$ & $1.20^{d}$ & $48.9^{b c}$ & 0 \\
\hline $\mathrm{TM}$ & $2.35^{c}$ & $9.12^{b c}$ & $13.03^{a b}$ & $7.07^{c d}$ & $2.49^{d}$ & $51.6^{b c}$ & 1 \\
\hline Unshaded & 7.69 & 16.21 * & $16.71 *$ & 6.45 & 1.79 & 55.3 & 2 \\
\hline NR & $6.67^{b c}$ & $24.44^{a}$ & - & - & - & $71.9^{a}$ & 0 \\
\hline C & $7.79 b c$ & $16.62^{a b}$ & $17.79^{a}$ & $5.16^{c d}$ & $1.23^{d}$ & $64.2^{a}$ & 0 \\
\hline $\mathrm{M}$ & $8.53^{b c}$ & $14.71^{a b}$ & $16.95^{a}$ & $6.92^{c d}$ & $1.45^{d}$ & $55.2^{b}$ & 1 \\
\hline $\mathrm{T}$ & $9.12^{b c}$ & $16.32^{a b}$ & $15.29^{a b}$ & $6.02^{c d}$ & $1.85^{d}$ & $49.0^{b c}$ & 1 \\
\hline $\mathrm{TM}$ & $5.59 b c$ & $15.00^{a b}$ & $17.35^{a}$ & $7.41^{c d}$ & $2.63^{d}$ & $48.6^{b c}$ & 0 \\
\hline
\end{tabular}



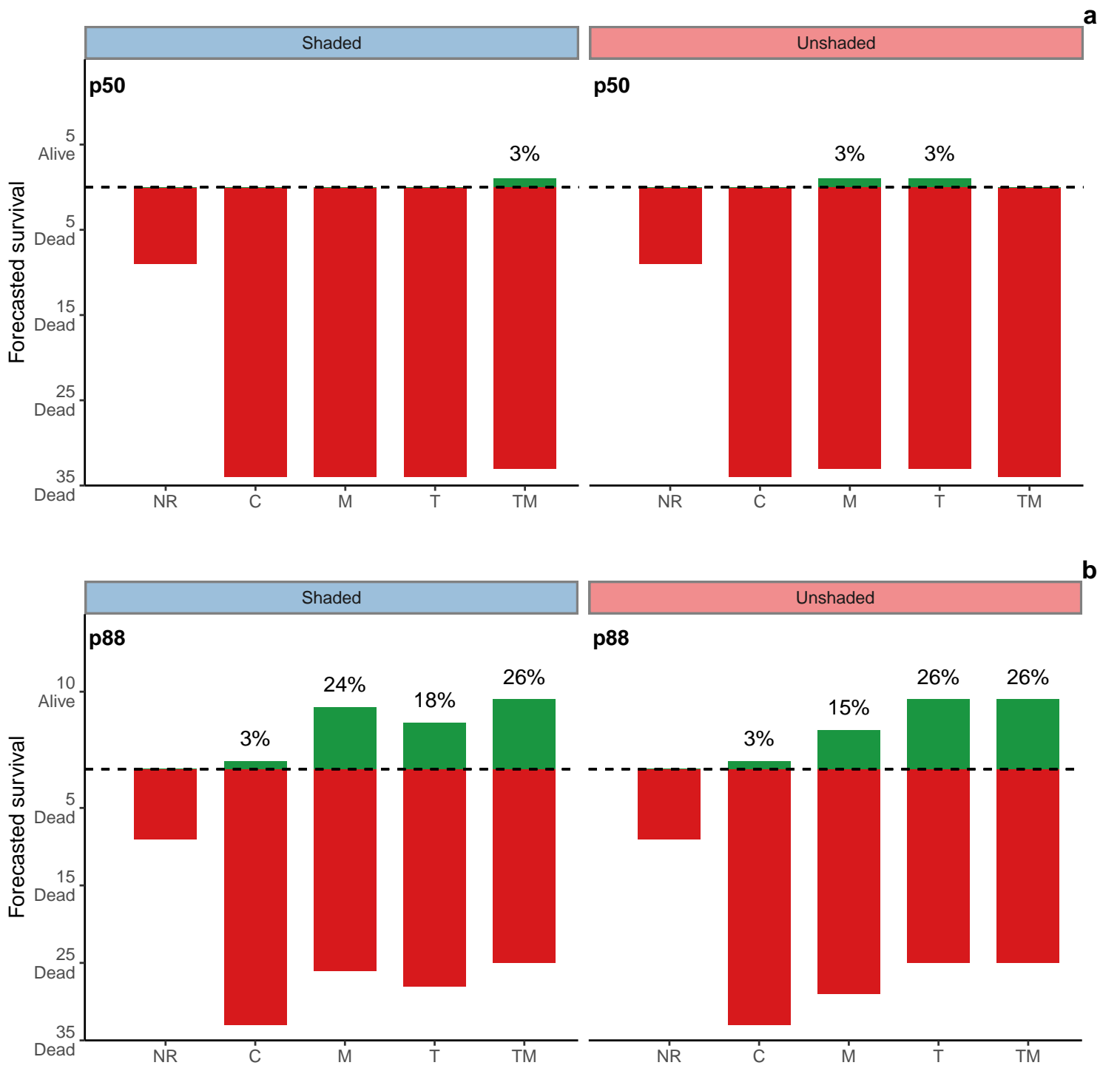

Figure 6. Inferred seedling survival and mortality based on the number of trees in each group with relative water loss < p50 (RWL $\leq 30.13 \%$; Panel (a)) and p88 (RWL $\leq 44.24 \%$; Panel (b)), based on estimates from Rosner et al. [41]. Green bars and percentages illustrate survival and red bars illustrate mortality.

Table 3. Average needle browning [\%], 24-h transpiration following watering treatments [g], relative water loss at the end of the experiment [RWL: \%], and number of trees with RWL below the p50 value for pondersoa pine subpopulations (AR: Arapaho-Roosevelt National Forests, PS: Pike \& San Isabel National Forests, SR: San Juan-Rio Grande National Forests) in shaded (47\% canopy cover) and unshaded ( $1 \%$ canopy cover) microsites. Letters indicate statistically significant differences within the 10 shelter-treatment subgroups, and stars indicate statistically significant groupings between sheltered and unsheltered microsites, determined by ANOVA and Tukey's honest significant differences $(p<0.05)$.

\begin{tabular}{|c|c|c|c|c|c|c|c|}
\hline & \multicolumn{2}{|c|}{ Needle Browning [avg \%] } & \multicolumn{3}{|c|}{ 24-h Transpiration [g] } & \multirow[b]{2}{*}{ RWL [avg \%] } & \multirow[b]{2}{*}{ Trees $\mathrm{RWL}<\mathrm{p} 50$} \\
\hline & Day 12 & Day 45 & Days 3-8 & Days 13-30 & Day 45 & & \\
\hline Shaded & 5.42 & $11.97 *$ & $14.27 *$ & 6.02 & 1.45 & 53.6 & 1 \\
\hline $\mathrm{AR}$ & $3.33^{f}$ & $10.10^{c d}$ & $13.75^{a}$ & $5.83^{b}$ & $1.30^{b}$ & $52.1^{b}$ & 1 \\
\hline PS & $1.76^{f}$ & $9.22^{c d e}$ & $14.61^{a}$ & $6.07^{b}$ & $1.49^{b}$ & $53.1^{a b}$ & 0 \\
\hline SR & $12.17^{b c}$ & $17.44^{a b}$ & $14.47^{a}$ & $6.17^{b}$ & $1.51^{b}$ & $56.0^{a b}$ & 0 \\
\hline
\end{tabular}


Table 3. Cont.

\begin{tabular}{|c|c|c|c|c|c|c|c|}
\hline & \multicolumn{2}{|c|}{ Needle Browning [avg \%] } & \multicolumn{3}{|c|}{ 24-h Transpiration [g] } & \multirow[b]{2}{*}{ RWL [avg \%] } & \multirow[b]{2}{*}{ Trees $\mathrm{RWL}<\mathrm{p} 50$} \\
\hline & Day 12 & Day 45 & Days 3-8 & Days 13-30 & Day 45 & & \\
\hline Unshaded & 7.69 & $16.21 *$ & $16.71 *$ & 6.45 & 1.79 & 55.3 & 2 \\
\hline AR & $5.10^{\mathrm{def}}$ & $13.33^{b c}$ & $15.65^{a}$ & $6.15^{b}$ & $1.71^{b}$ & $54.2^{a b}$ & 0 \\
\hline PS & $4.12^{e f}$ & $13.14^{b c}$ & $16.82^{a}$ & $6.17^{b}$ & $1.82^{b}$ & $53.3^{a b}$ & 2 \\
\hline SR & $15.00^{b c}$ & $23.26^{a}$ & $17.71^{a}$ & $7.20^{b}$ & $1.84^{b}$ & $59.1^{a}$ & 0 \\
\hline
\end{tabular}

\section{Discussion}

In this study we experimentally induced a 45-day moderate dry period in shaded and unshaded microsites in the Colorado Front Range, and assessed the hydraulic functioning and inferred the survival of planted ponderosa pine seedlings from 3 Colorado subpopulations in response to variation in the timing and magnitude of small rainfall events. We found that unshaded and partially shaded microsites had similar Ta and VPD, likely due to wind mixing, whereas unshaded microsites had significantly higher Ts and PAR (Objective 1). Small rainfall events of 4-6 mm increased VWC at $5 \mathrm{~cm}$ depth for 1-2 days, but for VWC at $12 \mathrm{~cm}$ only the highest rainfall treatment had this temporary effect (TM; Objective 2). Thus, the contribution of small rainfall events to soil moisture is limited to very shallow soil layers during dry periods, and this moisture is quickly depleted. Recharge of deeper soil moisture likely requires a very high frequency of small rainfall events, or larger ones. In refutation of our hypothesis, we found no difference in tree hydraulic functioning or inferred survival and mortality between experimental treatment groups or between seedlings in partially shaded and unshaded microsites. We also did not observe differences between Colorado ponderosa pine subpopulations, although the most southerly population (SR) experienced a significantly higher rate and magnitude of needle browning that may indicate a reduction in leaf area at stress onset. We postulate that the severe declines in tree hydraulic functioning and high inferred mortality that we found are likely due to the extended duration of our experimental period. We note that evidence of initiation of tree mortality at $\sim 13$ days corroborates similar findings by Augustine and Reinhardt [31] but was shorter than the 29 days observed by Sapes and Sala [45] in a greenhouse study. More nuanced responses across treatments occurred during the first half of the experiment, although required destructive sampling did not allow us to progressively infer tree mortality. Both shorter and longer moderate dry periods occur frequently in the Colorado Front Range, and our experiment better captures the effect of longer events. Future focus on the timing of soil moisture drydown, the initiation of seedling stress among ponderosa pine subpopulations, and comparison of naturally growing versus planted seedlings would help to provide more complete understanding of the role moderate dry periods in shaping regeneration success.

\subsection{Environmental Effects Shaping Dry Period Severity}

Although we did not observe differences in tree survival between shaded and unshaded microsites, it would be imprudent to conclude that fine-scale variation in landscape attributes and microclimate do not shape patterns of conifer regeneration and survival. Studies have reported higher ponderosa pine seedling establishment and survival associated with shrub-shaded microsites [24,46]. Heterogeneity in soil parent material and soil resources is also associated with variation in regeneration success. Higher soil clay content may be associated with greater juvenile conifer growth [13], although Puhlick et al. [26] found that sedimentary parent material, with its low clay content and low $\mathrm{pH}$, was associated with higher regeneration success compared to basalt derived soils with higher clay content. Natural soil biota can assuage the negative effects of stressful climate conditions [47]. In addition to soil, litter cover variation can have a large influence on regeneration success. Thick litter cover is both a barrier to seedling establishment in mineral soil after germination and can continue to be a barrier to juvenile growth after 
establishment $[10,13,48]$. Research elucidating the mechanistic influence of additional, finescale site characteristics on resource availability and conifer performance at early stages of development would be an excellent way to improve regeneration understanding.

Forest recovery following wildfire is declining and becoming increasingly challenging to achieve through management interventions that seek to replicate past post-wildfire regeneration patterns $[7,49,50]$. The unfavorability of post-wildfire landscapes for tree recovery (when seed sources are available) has been well-documented [5,14,51], and recent studies point to the further impact of climate change in making post-wildfire environments inhospitable for recovery, both across broad burned areas and within specific microenvironments such as south-facing aspects $[1,4,7,49,52]$. Additionally, high soil temperatures and complete removal of the litter layer during high severity wildfire are associated with a large decline in post-fire soil water infiltration $[53,54]$. Conifer seedlings may have higher establishment and survival in sheltered microsites, although plant-plant competition can suppress conifer regeneration $[51,55]$. Our study shows that even short duration declines in soil moisture availability will quickly initiate hydraulic stress in nursery-grown and planted conifer seedlings, even when microclimate conditions are much less severe than those found in post-wildfire landscapes. Thus, tree planting efforts in both undisturbed and post-wildfire landscapes can be improved by avoiding short-duration dry periods by adjusting the seasonal timing of planting or timing planting to co-occur with higher rainfall periods, or by ameliorating short-duration dry periods by planting trees in favorable microsites that support greater soil moisture availability.

\subsection{Seedling Functioning and Inferred Mortality}

Understanding how climate conditions, landscape attributes, and tree stress tolerance interact to shape regeneration success and failure is key for forecasting and managing regeneration in a changing environment. Yet it is especially challenging to pinpoint thresholds of stress and mortality in conifer seedlings ( $0-3$ y) and older juveniles. For example, juvenile ponderosa pine mortality is often identified at $90-100 \%$ needle browning $[8,56]$, yet the time from tree mortality to $90 \%$ brown needles may be as long as 10-20 weeks, such that an observably dead conifer has already been dead for some time [56,57]. Observation of brown needles is therefore adequate for identifying mortality, but is not able to pinpoint its occurrence. In our study we were able to measure tree transpiration as an immediate measure of hydraulic functioning [22]. Yet, it is unclear to what degree our mass-based determination of loss of function can be extended to in situ observation of naturally growing trees, and we recognize that attribution of loss of hydraulic function versus water limitation is tenuous. We did not observe evidence of physiological acclimation to drought as reported by Augustine and Reinhardt [31], and note that lack of acclimation is one pathway by which artificial regeneration of planted seedlings may strongly influenced by environmental stress. The way that nursery-grown ponderosa pines differ in growth, function, and stress tolerance compared to naturally growing trees is not well documented. McDonald et al. [58] found that planted seedlings had higher growth than naturally growing seedlings and argue that a year of nursery growth appears to give planted seedlings a growth advantage. However, Cregg [27] found that drought-hardened seedlings are able to persist for a longer period of time during dry periods, and Pinto et al. [34] observed low survival of nursery grown seedlings during an experimental drought. Importantly, naturally rejuvenated juveniles reach p50 at a more negative pressure than mature trees [29], and preliminary data from MEF collected by our group suggests that juvenile ponderosa pines are more resistant to cavitation than branches from mature trees (not shown). Thus, the growth advantage of nursery grown seedlings may be a disadvantage once they are transferred to dry conditions, and it is plausible that our findings of loss of hydraulic functioning and high inferred mortality may have been lessened for a population of naturally growing seedlings.

More accessible measures of conifer seedling stress and mortality are needed to inform the risk of regeneration failure. In situ measures of hydraulic functioning are possible using gas exchange instrumentation (see Augustine and Reinhardt [31] for an example), 
but are limited by the time required to conduct replicate measurements, especially in a field environment where environmental conditions vary over relatively short timescales. Quantification of hydraulic vulnerability (either via vulnerability curves or measures of RWL) in seedlings is also particularly difficult to conduct over time as it requires destructive sampling [39]. Hydraulic vulnerability is further complicated by the fact that juvenile and adult trees often differ $[28,29]$, and that vulnerability may often differ between populations of the same species growing in different local or regional environments [30,45]. Thus, a dichotomy remains between the fine scales of tree stress and mortality and the coarser scales at which they are currently observable. In our study, measurement of canopy temperature captured canopy cooling via latent energy exchange, providing a useful if indirect measure of functioning at a high level of temporal detail. Although it is not yet clear how to best implement and standardize remote sensing measures within the small and heterogeneous canopies of conifer seedlings, we postulate that there may be potential for remote sensing to enhance detection of seedling stress and mortality. Various remote sensing measures and indices including photochemical reflectance index (PRI), normalized difference vegetation index (NDVI), and hyperspectral band analysis have been used to identify adult conifer stress, often at relatively broad spatial scales and prior to onset of visual markers of stress [59-62]. Plant volumetric water content (VWC) is strongly related to mortality, and VWC is correlated with various remote sensing indices in angiosperms, but the connection between remote sensing indices and mortality has not been fully investigated in conifer seedlings or juveniles [63]. Development of techniques to implement spectral analyses at the scale and surface heterogeneity of conifer seedling canopies may be an especially useful way to gain novel insight on tree functioning, stress and mortality, and may be able to provide the temporal resolution required to link tree processes to variation in environmental conditions.

\subsection{Climate Change: Severe Pulse as Well as Moderate Press?}

Climate change is expected to intensify pulse disturbances including hotter droughts and greater wildfire activity [3,64], and reshape how ecosystems respond to and recover from disturbance $[5,65,66]$. It is clear that many arid and semiarid ecosystems will be strongly shaped by the future occurrence and spatiotemporal arrangement of positive and negative pulse events. Yet, press disturbances including higher air and soil temperatures, earlier snowmelt, and greater average aridity may have significant impacts through their independent effects on ecosystems and their ability to intensify pulse disturbances [67-70]. Continuous environmental change is reshaping North American ecosystems, with effects ranging from declining plant productivity in grasslands [71], to earlier seedling mortality during dry periods in forest-grassland ecotones [72], to increased tree mortality in old growth forests [73]. We found that commonly occurring moderate dry periods may limit the survival of planted ponderosa pine seedlings, and alleviation of stress requires more frequent or larger rainfall events that do not commonly occur during dry periods. Onsite meteorological measurements at MEF show that only 17 of the past 70 years (24\%) experienced early summer and fall dry periods with more than $36 \mathrm{~mm}$ of precipitation, the total rainfall of our highest experimental treatment (TM). Furthermore, increasing duration and severity of moderate dry periods due to increasing temperatures and greater evaporative demand are more likely than decreasing severity due to increasing rainfall. We caution that considerable uncertainty remains regarding seedling and juvenile conifer stress tolerance (for example, nursery versus natural trees, increasing tolerance with age), as well as the role of large and infrequent recruitment events that occur during favorable climatic periods. Yet, moderate dry periods are likely to be an important and likely increasing regulator of regeneration-associated forest persistence, with characteristics that typify a consistent seasonal press instead of episodic pulse disturbance. 


\section{Conclusions}

We experimentally induced a moderate dry period in shaded and unshaded ponderosa pine microsites, and assessed the hydraulic functioning and inferred the survival and mortality of planted ponderosa pine seedlings from 3 subpopulations in response to variation in the small rainfall events that typify these periods. We hypothesized that trees receiving more water and located in shaded microsites would maintain greater functioning and exhibit greater survival. Yet, we observed severe declines in tree hydraulic functioning and inferred high mortality across all treatments and microsite conditions. Specifically, we observed a decline in tree transpiration from all subpopulations after $\sim 10$ days that we attribute to sustained reductions in soil moisture availability. Our results show how declines in seedling function may be realized across variation in environmental stress imposed by moderate dry periods, and illustrate the short timescales over which initiation of stress may occur. Intensification of moderate dry periods may be an important and underrecognized component of natural and human-assisted ponderosa pine forest regeneration and persistence, especially when these events are a regular press disturbance that is already impactful in many years.

Supplementary Materials: The following supporting information can be downloaded at: https: / / www.mdpi.com/article/10.3390/f13030370/s1, Figure S1: Microsite characteristics; Figure S2: Needle browning; Table S1: Seed source and experimental site location and climate; Table S2: Transpiration explanatory variables, all trees; Table S3: Transpiration explanatory variables, shaded microsite trees; Table S4: Transpiration explanatory variables, unshaded microsite trees.

Author Contributions: Conceptualization, M.D.P. and R.M.H.; methodology, M.D.P. and R.M.H.; formal analysis, M.D.P. and C.R.K.; investigation, M.D.P., R.M.H. and C.R.K.; data curation, M.D.P., R.M.H. and C.R.K.; writing—original draft preparation, M.D.P., R.M.H. and C.R.K.; writing-review and editing, M.D.P.; visualization, M.D.P. and C.R.K.; supervision, M.D.P.; project administration, M.D.P. and R.M.H.; funding acquisition, M.D.P. and R.M.H. All authors have read and agreed to the published version of the manuscript.

Funding: This research was funded by the USDA Forest Service, Western Wildlands Environmental Threat Assessment Center grant number 20-JV-11221634-190.

Institutional Review Board Statement: Not applicable.

Informed Consent Statement: Not applicable.

Data Availability Statement: Experimental data are available from the corresponding author upon reasonable request.

Acknowledgments: This research was supported by a grant from the USDA Forest Service, Western Wildlands Environmental Threat Assessment Center (20-JV-11221634-190), and from the Graduate and Professional Student Association of University of Nevada, Las Vegas.

Conflicts of Interest: The authors declare no conflict of interest.

\section{References}

1. $\quad$ Davis, K.T.; Dobrowski, S.Z.; Higuera, P.E.; Holden, Z.A.; Veblen, T.T.; Rother, M.T.; Parks, S.A.; Sala, A.; Maneta, M.P. Wildfires and climate change push low-elevation forests across a critical climate threshold for tree regeneration. Proc. Natl. Acad. Sci. USA 2019, 116, 6193-6198. [CrossRef] [PubMed]

2. Petrie, M.D.; Bradford, J.B.; Hubbard, R.M.; Lauenroth, W.K.; Andrews, C.M.; Schlaepfer, D.R. Climate change may restrict dryland forest regeneration in the 21st century. Ecology 2017, 98, 1548-1559. [CrossRef]

3. Bradford, J.B.; Schlaepfer, D.R.; Lauenroth, W.K.; Palmquist, K.A. Robust ecological drought projections for drylands in the 21st century. Glob. Chang. Biol. 2020, 26, 3906-3919. [CrossRef]

4. $\quad$ Rodman, K.C.; Veblen, T.T.; Battaglia, M.A.; Chambers, M.E.; Fornwalt, P.J.; Holden, Z.A.; Kolb, T.E.; Ouzts, J.R.; Rother, M.T. A changing climate is snuffing out post-fire recovery in montane forests. Glob. Ecol. Biogeogr. 2020, 29, 2039-2051. [CrossRef]

5. Stevens-Rumann, C.S.; Kemp, K.B.; Higuera, P.E.; Harvey, B.J.; Rother, M.T.; Donato, D.C.; Morgan, P.; Veblen, T.T. Evidence for declining forest resilience to wildfires under climate change. Ecol. Lett. 2018, 21, 243-252. [CrossRef]

6. Minott, J.A.; Kolb, T.E. Regeneration patterns reveal contraction of ponderosa forests and little upward migration of pinyonjuniper woodlands. For. Ecol. Manag. 2020, 458, 117640. [CrossRef] 
7. Ouzts, J.; Kolb, T.; Huffman, D.; Sánchez Meador, A. Post-fire ponderosa pine regeneration with and without planting in Arizona and New Mexico. For. Ecol. Manag. 2015, 354, 281-290. [CrossRef]

8. Rother, M.T.; Veblen, T.T.; Furman, L.G. A field experiment informs expected patterns of conifer regeneration after disturbance under changing climate conditions. Can. J. For. Res. 2015, 45, 1607-1616. [CrossRef]

9. Kolb, T.E.; Flathers, K.; Bradford, J.B.; Andrews, C.; Asherin, L.A.; Moser, W.K. Stand density, drought, and herbivory constrain ponderosa pine regeneration pulse. Can. J. For. Res. 2020, 50, 862-871. [CrossRef]

10. Stein, S.J.; Kimberling, D.N. Germination, establishment, and mortality of naturally seeded southwestern ponderosa pine. West. J. Appl. For. 2003, 18, 109-114. [CrossRef]

11. Bailey, J.D.; Covington, W.W. Evaluating ponderosa pine regeneration rates following ecological restoration treatments in northern Arizona, USA. For. Ecol. Manag. 2002, 155, 271-278. [CrossRef]

12. White, A.S. Presettlement regeneration patterns in a southwestern ponderosa pine stand. Ecology 1985, 66, 589-594. [CrossRef]

13. Pirtel, N.L.; Hubbard, R.M.; Bradford, J.B.; Kolb, T.E.; Litvak, M.E.; Abella, S.R.; Porter, S.L.; Petrie, M.D. The aboveground and belowground growth characteristics of juvenile conifers in the southwestern United States. Ecosphere 2021, 12, e03839. [CrossRef]

14. Hankin, L.E.; Higuera, P.E.; Davis, K.T.; Dobrowski, S.Z. Impacts of growing-season climate on tree growth and post-fire regeneration in ponderosa pine and Douglas-fir forests. Ecosphere 2019, 10, e02679. [CrossRef]

15. Notaro, M.; Liu, Z.; Gallimore, R.G.; Williams, J.W.; Gutzler, D.S.; Collins, S. Complex seasonal cycle of ecohydrology in the Southwest United States. J. Geophys. Res. Biogeosci. 2010, 115, G04034. doi: 10.1029/2010JG001382. [CrossRef]

16. McDowell, N.G.; Allen, C.D.; Marshall, L. Growth, carbon-isotope discrimination, and drought-associated mortality across a pinus ponderosa elevational transect. Glob. Chang. Biol. 2010, 16, 399-415. [CrossRef]

17. Romme, W.H.; Clement, J.; Hicke, J.; Kulakowski, D.; MacDonald, L.H.; Schoennagel, T.L.; Veblen, T.T. Recent Forest Insect Outbreaks and Fire Risk in Colorado Forests: A Brief Synthesis of Relevant Research; Tech. Rep.; Colorado Forest Research Institute: Fort Collins, CO, USA, 2006.

18. Loik, M.E.; Breshears, D.D.; Lauenroth, W.K.; Belnap, J. A multi-scale perspective of water pulses in dryland ecosystems: Climatology and ecohydrology of the western USA. Oecologia 2004, 141, 269-281. [CrossRef]

19. Koehn, C.R.; Petrie, M.D.; Bradford, J.B.; Litvak, M.E.; Strachan, S. Seasonal precipitation and soil moisture relationships across forests and woodlands in the southwestern united states. J. Geophys. Res. Biogeosci. 2021, 126, e2020JG005986. [CrossRef]

20. League, K.; Veblen, T. Climatic variability and episodic Pinus ponderosa establishment along the forest-grassland ecotones of Colorado. For. Ecol. Manag. 2006, 228, 98-107. [CrossRef]

21. Petrie, M.D.; Wildeman, A.M.; Bradford, J.B.; Hubbard, R.M.; Lauenroth, W.K. A review of precipitation and temperature control on seedling emergence and establishment for ponderosa and lodgepole pine forest regeneration. For. Ecol. Manag. 2016, 361, 328-338. [CrossRef]

22. Kolb, P.F.; Robberecht, R. High temperature and drought stress effects on survival of Pinus ponderosa seedlings. Tree Physiol. 1996, 16, 665-672. [CrossRef] [PubMed]

23. Delucia, E.H.; Maherali, H.; Carey, E.V. Climate-driven changes in biomass allocation in pines. Glob. Chang. Biol. 2000, 6, 587-593. [CrossRef]

24. Keyes, C.R.; Maguire, D.A.; Tappeiner, J.C. Recruitment of ponderosa pine seedlings in the Cascade Range. For. Ecol. Manag. 2009, 257, 495-501. [CrossRef]

25. Gray, A.N.; Spies, T.A. Microsite Controls on Tree Seeling Establishment in Conifer Forest Canopy Gaps. Ecology 1997, 78, 2458-2473. [CrossRef]

26. Puhlick, J.J.; Laughlin, D.C.; Moore, M.M.. Factors influencing ponderosa pine regeneration in the southwestern USA. For. Ecol. Manag. 2012, 264, 10-19. [CrossRef]

27. Cregg, B.M. Carbon allocation, gas exchange, and needle morphology of Pinus ponderosa genotypes known to differ in growth and survival under imposed drought. Tree Physiol. 1994, 14, 883-898. [CrossRef]

28. Domec, J.; Warren, J.; Meinzer, F.; Lachenbruch, B. Safety factors for xylem failure by implosion and air-seeding within roots, trunks and branches of young and old conifer trees. IAWA J. 2009, 30, 101-120. [CrossRef]

29. Domec, J.-C.; Gartner, B.L. Relationship between growth rates and xylem hydraulic characteristics in young, mature and old-growth ponderosa pine trees. Plant Cell Environ. 2003, 26, 471-483. [CrossRef]

30. Anderegg, L.; HilleRisLambers, J. Drought stress limits the geographic ranges of two tree species via different physiological mechanisms. Glob. Chang. Biol. 2016, 22, 1029-1045. [CrossRef]

31. Augustine, S.P.; Reinhardt, K. Differences in morphological and physiological plasticity in two species of first-year conifer seedlings exposed to drought result in distinct survivorship patterns. Tree Physiol. 2019, 39, 1446-1460. [CrossRef]

32. Veblen, T.T.; Lorenz, D.C. The Colorado Front Range: A Century of Ecological Change; University of Utah Press: Salt Lake City, UT, USA, 1991.

33. Potter, K.M.; Hipkins, V.D.; Mahalovich, M.F.; Means, R.E. Mitochondrial DNA haplotype distribution patterns in Pinus ponderosa (Pinaceae): Range-wide evolutionary history and implications for conservation. Am. J. Bot. 2013, 100, 1562-1579. [CrossRef] [PubMed]

34. Pinto, J.R.; Marshall, J.D.; Dumroese, R.K.; Davis, A.S.; Cobos, D.R. Photosynthetic response, survival, and growth of three ponderosa pine stocktypes under water stress enhanced by vegetative competition. Can. J. For. Res. 2012, 42, 333-344. [CrossRef] 
35. Love, L.D.; Johnson, W.M. The Manitou Experimental Forest_Its Work and Aims; Station Paper 7; U.S. Forest Service, Rocky Mountain Forest and Range Experiment Station: Fort Collins, CO USA. 1952.

36. Soil Survey Staff; Natural Resources Conservation Service; United States Department of Agriculture. Web Soil Survey. 2020. Available online: http:/ / websoilsurvey.sc.egov.usda.gov (accessed on 3 March 2021).

37. PRISM Climate Group at Oregon State University. Prism Time Series Data. February 2004. Available online: http://prism. oregonstate.edu (accessed on 1 June 2020).

38. Petrie, M.D.; Pockman, W.T.; Pangle, R.E.; Limousin, J.M.; Plaut, J.A.; McDowell, N.G. Winter climate change promotes altered spring growing season in piñon pine-juniper woodlands. Agric. For. Meteorol. 2015, 214-215, 357-368. [CrossRef]

39. Martinez-Vilalta, J.; Anderegg, W.R.L.; Sapes, G.; Sala, A. Greater focus on water pools may improve our ability to understand and anticipate drought-induced mortality in plants. New Phytol. 2019, 223, 22-32. [CrossRef] [PubMed]

40. Hietz, P.; Rosner, S.; Sorz, J.; Mayr, S. Comparison of methods to quantify loss of hydraulic conductivity in Norway spruce. Ann. For. Sci. 2008, 65, 502. [CrossRef]

41. Rosner, S.; Johnson, D.M.; Voggeneder, K.; Domec, J.-C. The conifer-curve: Fast prediction of hydraulic conductivity loss and vulnerability to cavitation. Ann. For. Sci. 2019, 76, 82. [CrossRef]

42. Pammenter, N.W.; Van der Willigen, C. A mathematical and statistical analysis of the curves illustrating vulnerability of xylem to cavitation. Tree Physiol. 1998, 18, 589-593. [CrossRef]

43. R Core Team. R: A Language and Environment for Statistical Computing; R Foundation for Statistical Computing: Vienna, Austria, 2019. Available online: https:/ / www.R-project.org/ (accessed on 1 June 2020).

44. Barton, K. MuMIn: Multi-Model Inference. R Package Version 1.43.17. 2020. Available online: https://CRAN.R-project.org/ package=MuMIn (accessed on 1 October 2020).

45. Sapes, G.; Sala, A. Relative water content consistently predicts drought mortality risk in seedling populations with different morphology, physiology and times to death. Plant Cell Environ. 2021, 44, 3322-3335. [CrossRef]

46. Keyes, C.R.; Acker, S.A.; Greene, S.E. Overstory and shrub influences on seedling recruitment patterns in an old-growth ponderosa pine stand. Northwest Sci. 2001, 75, 204-210.

47. Remke, M.J.; Hoang, T.; Kolb, T.; Gehring, C.; Johnson, N.C.; Bowker, M.A. Familiar soil conditions help pinus ponderosa seedlings cope with warming and drying climate. Restor. Ecol. 2020, 28, S344-S354. [CrossRef]

48. Shepperd, W.D.; Edminster, C.B.; Mata, S.A. Long-Term Seedfall, Establishment, Survival, and Growth of Natural and Planted Ponderosa Pine in the Colorado Front Range. West. J. Appl. For. 2006, 21, 19-26. [CrossRef]

49. Rother, M.T.; Veblen, T.T. Limited conifer regeneration following wildfires in dry ponderosa pine forests of the Colorado Front Range. Ecosphere 2016, 7, e01594. [CrossRef]

50. Thompson, J.R.; Spies, T.A.; Ganio, L.M. Reburn severity in managed and unmanaged vegetation in a large wildfire. Proc. Natl. Acad. Sci. USA 2007, 104, 10743-10748. [CrossRef]

51. Welch, K.R.; Safford, H.D.; Young, T.P. Predicting conifer establishment post wildfire in mixed conifer forests of the North American Mediterranean-climate zone. Ecosphere 2016, 7, e01609. [CrossRef]

52. Boag, A.E.; Ducey, M.J.; Palace, M.W.; Hartter, J. Topography and fire legacies drive variable post-fire juvenile conifer regeneration in eastern Oregon, USA. For. Ecol. Manag. 2020, 474, 118312. [CrossRef]

53. Martin, D.A.; Moody, J.A. Comparison of soil infiltration rates in burned and unburned mountainous watersheds. Hydrol. Process. 2001, 15, 2893-2903. [CrossRef]

54. DeBano, L.F. The role of fire and soil heating on water repellency in wildland environments: A review. J. Hydrol. 2000, 231, 195-206. [CrossRef]

55. Tubbesing, C.L.; York, R.A.; Stephens, S.L.; Battles, J.J. Rethinking fire-adapted species in an altered fire regime. Ecosphere 2020, 11, e03091. [CrossRef]

56. Adams, H.D.; Barron-Gafford, G.A.; Minor, R.L.; Gardea, A.A.; Bentley, L.P.; Law, D.J.; Breshears, D.D.; McDowell, N.G.; Huxman, T.E. Temperature response surfaces for mortality risk of tree species with future drought. Environ. Res. Lett. 2017, $12,115014$. [CrossRef]

57. Hammond, W.M.; Yu, K.; Wilson, L.A.; Will, R.E.; Anderegg, W.R.; Adams, H.D. Dead or dying? Quantifying the point of no return from hydraulic failure in drought-induced tree mortality. New Phytol. 2019, 223, 1834-1843. [CrossRef]

58. McDonald, P.M.; Fiddler, G.; Ritchie, M.; Anderson, P. Naturally seeded versus planted ponderosa pine seedlings in groupselection openings. West. J. Appl. For. 2009, 24, 48-54. [CrossRef]

59. Santos, M.J.; Greenberg, J.A.; Ustin, S.L. Using hyperspectral remote sensing to detect and quantify southeastern pine senescence effects in red-cockaded woodpecker (Picoides borealis) habitat. Remote Sens. Environ. 2010, 114, 1242-1250. [CrossRef]

60. Grulke, N.; Maxfield, J.; Riggan, P.; Schrader-Patton, C. Pre-emptive detection of mature pine drought stress using multispectral aerial imagery. Remote Sens. 2020, 12, 2338. [CrossRef]

61. Huang, C.-Y.; Anderegg, W.R.L.; Asner, G.P. Remote sensing of forest die-off in the Anthropocene: From plant ecophysiology to canopy structure. Remote Sens. Environ. 2019, 231, 111233. [CrossRef]

62. Gamon, J.A.; Bond, B. Effects of irradiance and photosynthetic downregulation on the photochemical reflectance index in Douglas-fir and ponderosa pine. Remote Sens. Environ. 2013, 135, 141-149. [CrossRef]

63. Sapes, G.; Roskilly, B.; Dobrowski, S.; Maneta, M.; Anderegg, W.R.L.; Martinez-Vilalta, J.; Sala, A. Plant water content integrates hydraulics and carbon depletion to predict drought-induced seedling mortality. Tree Physiol. 2019, 39, 1300-1312. [CrossRef] 
64. Allen, C.D.; Breshears, D.D.; McDowell, N.G. On underestimation of global vulnerability to tree mortality and forest die-off from hotter drought in the Anthropocene. Ecosphere 2015, 6, 1-55. [CrossRef]

65. Latimer, C.E.; Zuckerberg, B. How extreme is extreme? Demographic approaches inform the occurrence and ecological relevance of extreme events. Ecol. Monogr. 2019, 89, e01385. [CrossRef]

66. Jentsch, A.; Beierkuhnlein, C. Research frontiers in climate change: Effects of extreme meteorological events on ecosystems. Comptes Rendus Geosci. 2008, 340, 621-628. [CrossRef]

67. Petrie, M.D.; Bradford, J.B.; Lauenroth, W.K.; Schlaepfer, D.R.; Andrews, C.M.; Bell, D.M. Non-analog increases to air, surface, and belowground temperature extreme events due to climate change. Clim. Chang. 2020, 163, 2233-2256. [CrossRef]

68. Gao, Y.; Leung, L.R.; Lu, J.; Liu, Y.; Huang, M.; Qian, Y. Robust spring drying in the southwestern US and seasonal migration of wet/dry patterns in a warmer climate. Geophys. Res. Lett. 2014, 41, 1745-1751. [CrossRef]

69. Harris, R.M.; Beaumont, L.J.; Vance, T.R.; Tozer, C.R.; Remenyi, T.A.; Perkins-Kirkpatrick, S.E.; Mitchell, P.J.; Nicotra, A.; McGregor, S.; Andrew, N.; et al. Biological responses to the press and pulse of climate trends and extreme events. Nat. Clim. Chang. 2018 8, 579-587. [CrossRef]

70. Cayan, D.R.; Das, T.; Pierce, D.W.; Barnett, T.P.; Tyree, M.; Gershunov, A. Future dryness in the southwest US and the hydrology of the early 21st century drought. Proc. Natl. Acad. Sci. USA 2010, 107, 21271-21276. [CrossRef]

71. Wu, Z.; Dijkstra, P.; Koch, G.W.; Hungate, B.A. Biogeochemical and ecological feedbacks in grassland responses to warming. Nat. Clim. Chang. 2012, 2, 458-461. [CrossRef]

72. Will, R.E.; Wilson, S.M.; Zou, C.B.; Hennessey, T.C. Increased vapor pressure deficit due to higher temperature leads to greater transpiration and faster mortality during drought for tree seedlings common to the forest-grassland ecotone. New Phytol. 2013, 200, 366-374. [CrossRef]

73. VanMantgem, P.J.; Stephenson, N.L.; Byrne, J.C.; Daniels, L.D.; Franklin, J.F.; Fulé, P.Z.; Harmon, M.E.; Larson, A.J.; Smith, J.M.; Taylor, A.H.; et al. Widespread increase of tree mortality rates in the western United States. Science 2009, 323, 521-524. [CrossRef] 